\title{
КОНЦЕПТИ КОМУНІКАТИВНОГО РЕСУРСУ У ХВОРИХ НА РЕКУРЕНТНИЙ ДЕПРЕСИВНИЙ РОЗЛАД ТА ÏХ РЕФЕРЕНТНИХ РОДИЧІВ
}

\author{
Вінницький національний медичний університет ім. М.І Пирогова, м. Вінниця, Україна
}

\begin{abstract}
Мета - визначення особливостей комунікативних ресурсів у хворих на рекурентний депресивний розлад (РДР) та їх рефрерентних родичів в контексті їх соціального фрункціонування.

Матеріали і методи. В якості психодіагностичного інструментарію дослідження використані методика Дж. Гілфрорда та М. Саллівена (російськомовна адаптація Михайлової Є. С.) та методика вимірювання емоційної емпатії A. Mehrabian. За умови інфрормованої згоди було обстежено 45 сімей, в яких проживає хворий на РДР, та, відповідно, 45 пацієнтів. Контрольну групу склали 35 сімей, в яких немає психічно хворих.

Результати. Показники емпатичної та афрфіліативної тенденцій були достовірно нижчими, а за шкалою «чутливість до знехтування» - достовірно вищими в групі хворих на РДР, порівняно з респондентами контрольної групи ( $<<0,001)$. Композитне оцінювання рівня соціального інтелекту свідчить про те, що у ресрерентних родичів пацієнтів з РДР адаптаційні ресурси особистості в міжособистісній взаємодії знижені (РДР $(3,66 \pm 0,2)$, КГ $(4,43 \pm 0,6)$ $\mathrm{P}<0,05)$.

Висновки. 1. Труднощі у розумінні та прогнозуванні поведінки людей пов'язані з особливостями комунікативного ресурсу особистості, до концептів якого можна віднести емпатично-аффріліативний статус та рівень соціального інтелекту.

2. У пацієнтів з РДР виявлено знижену здатність до співпереживання ситуації, зменшення потреби в активному спілкуванні, звуження кола інтересів, погіршення міжособистісної комунікації. На фонні недостатньо розвинених емпатично-аффріліативних тенденцій відзначається підвищений рівень сенситивності до знехтування у спілкуванні, що може бути предиктором формування дезадаптивних поведінкових паттернів.

3. Наявність низького комунікативного ресурсу як у хворих з РДР, так і у їх референтних родичів значно ускладнює стосунки у сім'ях хворих, знижує можливості соціальної адаптації членів комунікативного процесу та порушує гомеостаз сімейної системи, що необхідно враховувати при створенні відповідних психоосвітніх та психокорекційних програм.
\end{abstract}

КЛЮчОВІ СЛОВА: рекурентний депресивний розлад; емпатія; афффіліація; соціальний інтелект.

Вступ. Комунікативні ресурси (КР) є підґрунтям, завдяки якому особистість не лише долає проблемні ситуації, а й адаптується у соціумі. Саме завдяки комунікативним психологічним ресурсам формується адаптивний чи неадаптивний поведінковий стиль, основу якого, в першу чергу, складають процеси емпатії, афрфіліації, психологічного захисту, локус контролю, самооцінка особистості. В ситуації, коли хвороба, з одного боку, змінює повністю особистісну структуру та сприяє нівелюванню й пригніченню емоційної сфери, а 3 іншого - ускладнює формування адекватної міжособистісної комунікації як у колі сім'ї, так і у соціумі загалом, нагальною стає проблема дослідження основних комунікативних ресурсів у пацієнтів, які хворіють на рекурентний депресивний розлад (РДР) та їх рефрерентних родичів (РР). Загальновідомо, що поява в сім'ї психічно хворої людини негативно вливає на якість життя як самого хворого,

(с) Н.Г. Пшук, А.О. Камінська, 2017 так і його родичів. Змінюються міжособистісні стосунки, подекуди виникають стани підвищеної дратівливості та немотивованої агресії, або ж, навпаки, стани надто зниженого енергетичного потенціалу особистості 3 обмеженими функціональними (емоційно-вольовими) можливостями. Все це призводить до порушення психологічних компенсаторно-адаптаційних реакцій та станів у родичів пацієнтів 3 РДР, тобто з'являються передумови для психосоціальної дезадаптації ресрерентних родичів. Наскільки члени сім'ї здатні формувати адекватні стосунки та адаптуватись до нових умов життя залежить від їх особистісного комунікативного ресурсу, до основних видів якого можна віднести соціальний інтелект, емпатію, аффріліацію. Низький рівень комунікативного ресурсу сприяє фрормуванню пасивної дезадаптивної поведінки, соціальній ізоляції та дезінтеграції особистості [1, 2]. Емпатія $€$ важливим ресурсом подолання проблемних та емоційно-стресових ситуацій. Між тим, 
до нинішнього часу немає однозначного визначення щодо фрормулювання цього френомену [3-7]. Розвинені навички емпатії на основі альтруїстичної мотивації дозволяють долати і власний стрес, і надавати допомогу в подоланні дистресу особі, яка потребує співпереживання. Недорозвиток навичок емпатії сприяє фрормуванню егоїстичної мотивації в емоційній відповіді. Така мотивація спрямована, передусім, на збереження власного благополуччя, редукцію власної емоційної напруги [8, 9]. Афрфіліація - це намагання людини бути серед людей та спілкуватись $з$ ними. Пригнічення потреби в афрфіліації викликає почуття ізольованості, самотності. В стресових ситуаціях потреба в афффіліації збільшується [10]. Емпатійно-афрфіліативні ресурси $€$ соціально-психологічним конструктом, який включає когнітивний, афективний та поведінковий компоненти і визначає систему емоційного та раціонального міжособистісного розуміння. В якості додаткового чинника, що сприяє розвитку комунікативних копінг-ресурсів, розглядається соціальний інтелект, який є базисом для реалізації емпатично-афроріліаційних тенденцій.

Мета дослідження - визначення особливостей комунікативних ресурсів у хворих на рекурентний депресивний розлад (РДР) та їх референтних родичів в контексті їх соціального функціонування.

Матеріали і методи. За умови інформованої згоди на базі Вінницької обласної психоневрологічної лікарні ім. О.І. Ющенка, було обстежено 45 сімей, у яких проживає хворий на РДР, та, відповідно, 45 пацієнтів. Обстежені хворі перебували у віці від 26 до 53 років (в середньому $(39,1 \pm 0,8)$ років). Тривалість спостереження цих хворих відповідала вимогам MKX-10 та була не менше року. Середній вік маніфестації захворювання - $(29,9 \pm 0,5)$ років. Серед обстежених пацієнтів було 25 жінок та 20 чоловіків. 3 них 27 лікувались двічі стаціонарно, 16 тричі. 27 з них мали власну сім'ю, 18 - проживали з батьками. Тривалість захворювання становила в середньому 2,4 року. За синдромологічною систематикою у 17,7 \% діагностовано астенодепресивний синдром, у 33,3 \% - тривожно-депресивний, депресивно-іпохондричний та депресивно-фробічний - у 28,8 \% та 20,0 \% відповідно. В якості респондентів групи РР були обстежені чоловік чи дружина та один з батьків (середній вік $(49,8 \pm 1,2)$ років). 53,3 \% сімей охарактеризували власний матеріальний стан як незадовільний. 77,5 \% сімей констатували порушення міжособистісних стосунків у сім'ї, що виникли внаслідок появи у сім'ї хворого на РДР. Контрольну групу склали 35 сімей, де не проживають психічно хворі (КГ). Методи дослідження: клініко-анамнестичний, соціальнодемографрічний, клініко-психопатологічний, психометричний, статистичний. Верифікація діагнозу за критеріями MKX-10 включала в себе збір анамнезу та визначення психічного статусу пацієнтів, даних медичної документації. Оцінювання особистісних комунікативних ресурсів (КР) «емпатія, афрфіліація, чутливість до знехтування» проводилась адаптованою методикою виміру емоційної емпатії A. Mehrabian [5]. Для оцінки рівня соціального інтелекту використовували методику Дж. Гілфрорда та М. Саллівена (російськомовна адаптація Михайлової Є.С. Дослідження соціального пізнання через соціальний інтелект як фрактора психосоціальної адаптації дозволяє розуміти та прогнозувати поведінку людей в різних життєвих ситуаціях, розпізнавати наміри, почуття та емоційні стани людини за вербальною та невербальною експресією. Методика визначає як загальний рівень соціального інтелекту, так і окремі його складові (здатність передбачати наслідки поведінки, розуміти вербальну та невербальну поведінку, розбиратися в загальній картині міжособистісної взаємодії). Для обстеження рефрерентних родичів (РР) хворих 3 РДР був використаний повний варіант методики. Результати оцінювали за 4 субтестами (СТ, СТ1 «історії з завершенням», СТ2 - «групи експресії», СТ3 - «невербальна експресія», СТ4 - «історії 3 доповненням»), а також враховувалась композитна оцінка.

Результати досліджень та їх обговорення. Дослідження «емпатичної» та «афрфіліативної» тенденцій, «сенситивності до знехтування» у хворих на РДР та здорових респондентів наведені в таблиці 1.

Статистично достовірні відмінності між показниками КР хворих на РДР та респондентів КГ були виявлені за всіма трьома субшкалами, де дані щодо емпатичної та афрфіліативної тенденцій були достовірно нижчими в групі хворих, а за шкалою «чутливість до знехтування» достовірно вищими, у порівнянні 3 даними щодо осіб, які були обстежені у групі контролю ( $p<0,001)$. За субшкалою

Таблиця 1. Рівень особистісних комунікативних копінг-ресурсів у пацієнтів з рекурентним депресивним розладом та респондентів групи контролю

(бал, $\mathrm{M} \pm \mathrm{m}$ )

\begin{tabular}{|l|c|c|c|}
\hline \multirow{2}{*}{ Копінг-ресурси } & \multicolumn{2}{|c|}{ Групи обстежених } & \multirow{2}{*}{$\mathrm{p}<0,05$} \\
\cline { 2 - 4 } & $\mathrm{PДP,} \mathrm{n}=45$ & $26,7 \pm 0,31$ & 0,001 \\
\hline Емпатія & $11,2 \pm 0,41$ & $23,4 \pm 0,12$ & 0,001 \\
\hline Асрфріліація & $12,3 \pm 0,87$ & $10,8 \pm 0,13$ & 0,001 \\
\hline Сенситивність до знехтування & $14,6 \pm 0,53$ & & 0 \\
\hline
\end{tabular}


«емпатичні тенденції» у хворих на РДР показники реєструвались у діапазоні від 8 до 19 балів (в середньому $(11,2 \pm 0,41)$ балів). У контрольній групі бальна оцінка варіювала від 13 до 34 балів (середні показники становили $(26,7 \pm 0,31)$ бала). Середньостатистичні показники аффріліації у хворих на РДР достовірно відрізнялись від аналогічних показників у осіб, які перебували у групі контролю (відповідно $(12,3 \pm 0,87)$ та $(23,4 \pm 012)$ балів; p<0,001). Показники варіювали від 15 до 37 балів. Сума балів за субшкалою «сенситивність до знехтування» була значно вищою у хворих на РДР (в середньому $(14,6 \pm 0,53)$ бала). В групі контролю відповідний показник становив $(10,8 \pm 0,13)$ бала. Діапазон індивідуальних відмінностей коливався від 8 до 29 балів у хворих з РДР та від 4 до 17 балів у респондентів групи контролю. Композитна оцінка у хворих на РДР становила 38,2 бала, що відповідало низькому рівню емпатії (в групі контролю 60,9 балів, що відповідало нормальному рівню емпатії).

Пацієнти з низьким рівнем емпатії мали проблеми у інтерперсональній комунікації, подекуди були схильні звинувачувати оточуючих у власній хворобі, з труднощами вступали у терапевтичний альянс з лікарем, не відповідали емоційному резонансу під час співбесіди. Вони не виявляли хвилювання за долю близьких людей, а їх думки були сфокусовані виключно на темі власного здоров'я. Тобто, у пацієнтів з РДР знижується здатність до співпереживання ситуації, зменшується потреба в активному спілкуванні, звужується коло інтересів, погіршується міжособистісна комунікація. Дещо емоційносплощена позиція хворих, їх намагання нав'язати свою точку зору, бажання підпорядкувати інтереси оточуючих власним інтересам впливали на когнітивну оцінку пацієнтів з РДР. Проявом цього була нездатність зрозуміти внутрішній світ іншої людини, відсутність уміння встановлювати контакти в процесі міжособистісної взаємодії, нездатність отримати необхідну підтримку за умови наявної проблеми, емоційна самотність. Саме такі психологічні особливості сприяли розвитку поведінки самоізоляції та уникнення. На фроні недостатньо розвинених емпатично-аффріліативних тенденцій підвищувався рівень сенситивності до знехтування у спілкуванні, що може слугувати предиктором фрормування дезадаптивних поведінкових паттернів.

У референтних родичів пацієнтів з РДР показники емпатично-афріліативного процесу відповідали низькому рівню (табл. 2).

Таблиця 2. Рівень особистісних комунікативних копінг-ресурсів референтних родичів пацієнтів 3

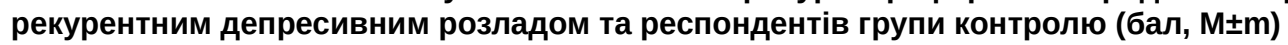

\begin{tabular}{|c|c|c|c|}
\hline \multirow{2}{*}{ Копінг-ресурси } & \multicolumn{2}{|c|}{ Групи обстежених } & \multirow{2}{*}{$\mathrm{p}<0,05$} \\
\cline { 2 - 4 } & РДР, $\mathrm{n}=45$ & $26,7 \pm 0,31$ & 0,001 \\
\hline Емпатія & $14,1 \pm 0,11$ & $23,4 \pm 0,12$ & 0,001 \\
\hline Асроіліація & $12,3 \pm 0,87$ & $10,8 \pm 0,13$ & 0,001 \\
\hline Сенситивність до знехтування & $10,6 \pm 0,53$ & $\mathrm{~N}=35$ & \\
\hline
\end{tabular}

Ступінь соціального фрункціонування сім'ї будьякої категоріальної приналежності залежить від рівня міжособистісної взаємодії, відображенням якої $€$ фрункція соціального пізнання через певний ступінь соціального інтелекту. Соціальний інтелект це інтегральна характеристика, яка забезпечує розуміння вчинків інших та їх дій, невербальної комунікації, тих чи інших та не зовсім звичних особливостей поведінки, що безперечно впливає на ефрективність лікувально-реабілітаційного процесу.

Дослідження рівня соціального інтелекту референтних родичів пацієнтів з РДР (табл. 3) дозволило виявити деякі відмінності, порівняно з особами групи контролю (РP $(3,49 \pm 0,9) ;$ КГ $(4,08 \pm 0,5)$ р<0,05).

Так, за першим субтестом «історії з завершенням» методики дослідження соціального інтелекту

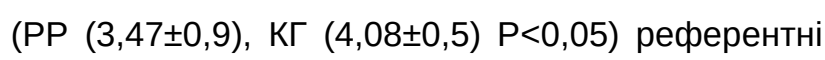
родичі мали посередні здібності щодо пізнання поведінки пацієнта, який хворіє на РДР, в умовах сім'ї. Вони могли лише частково передбачати подальші дії пацієнта на основі аналізу реальних ситуацій сімейного та дружнього спілкування, розуміти почуття хворого, i, на цій основі, визначати есрективність комунікації.

Встановлені циорові дані по першому субтесту дозволяють дійти висновку про те, що референтні родичі хворих на РДР не завжди можуть чітко будувати стратегію власної поведінки з метою досягнення певних цілей у лікуванні хворих. Їх поведінка може виходити за межі загальноприйнятих норм, вони невірно уявляють результати власних дій та вчинків інших. За другим субтестом «групи

Таблиця 3. Показники рівня соціального інтелекту референтних родичів пацієнтів з рекурентним депресивним розладом (середній бал, $\mathrm{M \pm m}$ )

\begin{tabular}{|c|c|c|c|c|c|}
\hline Группа & СТ1 & СТ2 & СТ3 & CT4 & КО \\
\hline PP $(n=76)$ & $3,49 \pm 0,9^{\star}$ & $3,14 \pm 1,6^{\star \star}$ & $3,08 \pm 1,1^{\star \star}$ & $3,47 \pm 0,5^{\star \star}$ & $3,66 \pm 0,2^{\star \star}$ \\
\hline КГ $(n=55)$ & $4,08 \pm 0,5$ & $4,18 \pm 0,1$ & $4,13 \pm 0,7$ & $4,49 \pm 0,2$ & $4,43 \pm 0,6$ \\
\hline
\end{tabular}

Примітка. * - показники є статистично достовірними $(\mathrm{P}<0,05) ;{ }^{*}-(\mathrm{P}<0,001)$. 
експресії» (РДР $(3,14 \pm 1,6) ;$ КГ $(4,18 \pm 0,1), \mathrm{P}<0,001)$ встановлені показники дозволяють думати про те, що рефрерентні родичі, на відміну від респондентів контрольної групи, мають утруднення в оцінці станів та почуттів за їх невербальними ознаками в процесі міжособистісної комунікації. Коли рефрерентні родичі хворих на РДР будують власну лінію поведінки, вони частіше орієнтуються на поодинокі вислови співрозмовників, аніж на прояви їх невербальної комунікації. У їх розумінні відкритість та доброзичливість не завжди є запорукою успіху у спілкуванні, у них знижена чутливість до емоційних станів інших людей і не завжди правильно вони оцінюють власний емоційний статус у спілкуванні, що безперечно є прямим чинником, яким зумовлена дисфуункціональність у комунікації. Чутливість до невербальної експресії суттєво посилює здатність розуміти інших. Здатність читати невербальні сигнали іншої людини, усвідомлювати їх та порівнювати з вербальними, $є$ основою інтуїції. Показники субтесту «вербальна експресія» (РДР $(3,08 \pm 1,1)$; КГ $(4,13 \pm 0,7) ; \mathrm{P}<0,001)$ вказують на те, що у референтних родичів, в сім'ях яких проживає пацієнт з афеективними розладами, знижується здатність швидко та вірно оцінювати мовну продукцію співбесідника в контексті певної ситуації, вірно знаходити відповідний тон спілкування; вони не завжди вірно проявляють рольову пластичність та розуміння сенсу вербальної комунікації. Результати, які ми отримали за четвертим субтестом «історії з доповненням» (РДР $(3,47 \pm 0,5)$; КГ, відповідно, $(4,49 \pm 0,2) \mathrm{P}<0,001)$, показують знижену здатність родичів хворих на РДР до вміння аналізувати складні ситуації взаємодії у міжособистісному спілкуванні; вони не завжди вірно можуть оцінити адекватність ситуації для спілкування та передбачити, як буде поводитись людина в подальшому, відшукати причини такої поведінки. Вони відчувають труднощі в оцінці потреби та намірів комунікації, прогнозуванні своєї поведінки та логіки подальших подій. Композитне оцінювання (РДР $(3,66 \pm 0,2)$; КГ $(4,43 \pm 0,6) \mathrm{P}<0,05)$ свідчить про те, що у референтних родичів пацієнтів з РДР знижені адаптаційні ресурси особистості в міжособистісній взаємодії, вони відчувають утруднення в судженнях про співрозмовника, малоконтактні, але більш тактовні та доброзичливі у комунікативній взаємодії у порівнянні з респондентами контрольної групи.

Висновки. 1. Труднощі у розумінні та прогнозуванні поведінки людей пов'язані з особливостями комунікативного ресурсу особистості, до концептів якого можна віднести емпатично-аффріліативний статус та рівень соціального інтелекту.

2. У пацієнтів з РДР виявлено знижену здатність до співпереживання ситуації, зменшення потреби в активному спілкуванні, звуження кола інтересів, погіршення міжособистісної комунікації. На фоні недостатньо розвинених емпатично-афрфіліативних тенденцій відзначається підвищений рівень сенситивності до знехтування у спілкуванні, що може бути предиктором формування дезадаптивних поведінкових паттернів.

3. Наявність низького комунікативного ресурсу як у хворих з РДР, так і у їх РР значно ускладнюють взаємовідносини у сім'ях хворих, знижують можливості соціальної адаптації членів комунікативного процесу та порушують гомеостаз сімейної системи.

Перспективи подальших досліджень. Виявлені закономірності слід враховувати при розробці відповідних комплексних психоосвітніх, психопрофрілактичних та психокорекційних програм для ресрерентних родичів, які проживають спільно 3 хворими, що мають афективні розлади.

\section{Список літератури}

1. Evaluation of the acceptability and usefulness of an information website for caregivers of people with bipolar disorder / L. Berk, M. Berk, S. Dodd [et al.] // BMC Medicine. - 2013. - № 11. - P. 162.

2. Chatzidamianos G. Qualitative analysis of relatives', health professionals' and service users' views on the involvement in care of relatives in Bipolar Disorder / G. Chatzidamianos, F. Lobban, S. Jones // BMC Psychiatry. - 2015. - № 15 (2). - P. 228. 3. Davis L. Adapters, strugglers, and case managers: a typology of spouse caregivers / L. L. Davis, D. Chestnutt // Qualitative Health Research. - 2014. - № 24 (11). - P. 1492-1500.

4. Epa R. Theory of mind, empathy and moral emotions in patients with affective disorders / R. Epa, D. Dudek // Archives of Psychiatry and Psychotherapy. - 2015. - № 2 (1) - P. 49-56.

5. Manczak E. M. Does empathy have a cost? Diverging psychological and physiological effects within families / E. M. Manczak, A. DeLongis, E. Chen // Health Psychology. - Official Journal of the Division of Health Psychology, American Psychological Association. - 2016. - № 35 (3). - P. 211-218.

6. Miklowitz D. J. Family treatment for bipolar disorder and substance abuse in late adolescence / D. J. Miklowitz // Journal of Clinical Psychology. - 2012. - № 68 (5) - P. 502-513.

7. Nadkarni R. B. Stress and support for parents of youth with bipolar disorder / R. B. Nadkarni, M. A. Fristad // The Israel Journal of Psychiatry and Related Sciences. - 2012. - № 49 (2). - P. 104-110.

8. Narasipuram S. Quality of life and perception of burden among caregivers of persons with mental illness / S. Narasipuram, S. Kasimahanti // AP J. Psychol. Med. Am. J. Nurs. - 2012. - № 13 (2). - P. 99-103.

9. Impact of living with bipolar patients: Making sense of caregivers' burden / M. Pompilli, D. Harnic [et al.] // World Journal of Psychiatry. - 2014. - № 4 (1). - P. 1-12.

10. Schreiter S. Empathy in adults with clinical or subclinical depressive symptoms / S. Schreiter, G. H. M. Pijnenborg, M. Aan het Rot // Journal of Affective Disorders. - 2013. - № 150. - P. 1-16. 


\section{References}

1. Berk, L., Berk, M., Dodd, S., Kelly, C., Cvetkovski, S., \& Jorm, A.F. (2013). Evaluation of the acceptability and usefulness of an information website for caregivers of people with bipolar disorder. BMC Medicine, 11(1), 162.

2. Chatzidamianos, G., Lobban, F., \& Jones, S. (2015). A qualitative analysis of relatives', health professionals' and service users' views on the involvement in care of relatives in Bipolar Disorder. BMC Psychiatry, 15, 228.

3. Davis, L.L., Chestnutt, D., Molloy, M., Deshefy-Longhi, T., Shim, B., \& Gilliss, C.L. (2014). Adapters, strugglers, and case managers: a typology of spouse caregivers. Qualitative Health Research, 24 (11), 1492-1500.

4. Epa, R., Dudek D. (2015). Theory of mind, empathy and moral emotions in patients with affective disorders. Archives of Psychiatry and Psychotherapy, 2, 49-56

5. Manczak, E. M., DeLongis, A., \& Chen, E. (2016). Does empathy have a cost? Diverging psychological and physiological effects within families. Health Psychology: Official Journal of the Division of Health Psychology, American Psychological Association, 35 (3), 211-218.

6. Miklowitz, D.J. (2012). Family treatment for bipolar disorder and substance abuse in late adolescence. Journal of Clinical Psychology, 68 (5), 502-513.

7. Nadkarni, R.B., \& Fristad, M.A. (2012). Stress and support for parents of youth with bipolar disorder. The Israel Journal of Psychiatry and Related Sciences, 49 (2), 104-110.

8. Narasipuram, S., \& Kasimahanti, S. (2012). Quality of life and perception of burden among caregivers of persons with mental illness. AP J. Psychol. Med., 13 (2), 99-103

9. Pompili, M., Harnic, D., Gonda, X., Forte, A., Dominici, G., Innamorati, M., \& Girardi, P. (2014). Impact of living with bipolar patients: Making sense of caregivers' burden. World Journal of Psychiatry, 4 (1), 1-12.

10. Schreiter, S., Pijnenborg, G. H. M., \& Aan het Rot, M. (2013). Empathy in adults with clinical or subclinical depressive symptoms. Journal of Affective Disorders, 150, 1-16.

\section{КОНЦЕПТЫ КОММУНИКАТИВНОГО РЕСУРСА У ПАЦИЕНТОВ С РЕКУРРЕНТНЫМ ДЕПРЕССИВНЫМ РАССТРОЙСТВОМ И ИХ РЕФЕРЕНТНЫХ РОДСТВЕННИКОВ}

Н.Г. Пшук, А.А. Каминская

Винницкий национальный медицинский университет им. Н.И. Пирогова, г. Винница, Украина

Цель-определение особенностей коммуникативных ресурсов упациентов с рекуррентным депрессивным расстройством (РДР) и их референтных родственников в контексте их социального фрункционирования.

Материалы и методы. В качестве психодиагностического инструментария исследования были использованы методика Дж. Гилфорда и М. Салливена (русскоязычная адаптация Михайловой Е. С.) и методика измерения эмоциональной эмпатии A. Mehrabian. При условии соблюдения информированного согласия было обследовано 45 семей, в которых проживает больной с РДР и, соответственно, 45 пациентов. Контрольную группу составили 35 семей, в которых нет психически больных.

Результаты. Показатели эмпатической и аффилиативной тенденций были достоверно ниже, а по шкале «чувствительность к пренебрежению» - достоверно выше в группе пациентов с РДР, в сравнении с респондентами контрольной группы $(p<0,001)$. Композитная оценка уровня социального интеллекта свидетельствует о том, что у референтных родственников пациентов с РДР адаптационные ресурсы

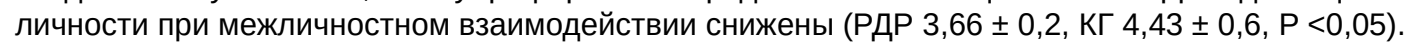

Выводы. 1. Трудности в понимании и прогнозировании поведения окружающих людей связаны с особенностями коммуникативного ресурса личности, к ведущим концептам которого можно отнести эмпатически-аффрилиативный статус и уровень социального интеллекта.

2. У пациентов с РДР обнаружены сниженная способность к сопереживанию ситуации, уменьшение потребности в активном общении, сужение круга интересов, ухудшение межличностной коммуникации. На фроне недостаточно развитых эмпатически-аффилиативных тенденций отмечается повышенный уровень сенситивности к пренебрежению в общении, что может быть предиктором фрормирования дезадаптивных поведенческих паттернов.

3. Наличие низкого коммуникативного ресурса как у больных с РДР, так и у их референтных родственников значительно затрудняет взаимоотношения в семьях больных, снижает возможности социальной адаптации членов коммуникативного процесса и нарушает гомеостаз семейной системы, что необходимо учитывать при разработке соответствующих психообразовательных и психокоррекционных программ.

КЛЮЧЕВЫЕ СЛОВА: рекуррентное депрессивное расстройство; эмпатия; аффрилиация; социальный интеллект.

\section{CONCEPTS OF COMMUNICATIVE RESOURCE IN PATIENTS WITH RECURRENT DEPRESSIVE DISORDER AND THEIR REFERENCE RELATIVES}

N. H. Pshuk, A. O. Kaminska

M. Pyrohov Vinnytsia National Medical University, Vinnytsia, Ukraine

The aim of the work - to determine the main characteristics of communication resources in patients with recurrent depressive disorder (RDR) and their reference relatives in social functioning context. 
Materials and Methods. J. Sullivan and M. Guilford questionnaire and method of emotional empathy measuring by A. Mehrabian were used as psychological testing tools. After getting the informed consent, 45 families with a RDR patient and therefore 45 patients were included into our study. Control group included 35 families that do not have mentally sick members.

Results. Indicators of empathic and affiliative tendencies were significantly lower, while indicators for the scale of "sensitivity to neglecting" were significantly higher in patients with RDR compared to respondents of control group $(p<0.001)$. Composite evaluation of social intelligence in reference relatives of patients with RDR indicates that their individual adaptation resources in interpersonal interaction are reduced (RDR $3.66 \pm 0.2, \mathrm{~kg} 4.43 \pm 0.6, p<0.05$ ).

Conclusions. 1. Difficulties in understanding and predicting behavior of other people are associated with certain peculiarities of individual communication resources which include empathy, affiliation and social intelligence level.

2. Patients with RDR revealed reduced capacity for empathy in social situations, reduced need for active communication, narrow range of interests, deterioration of interpersonal communication. High level of sensitivity towards neglecting on the background of underdeveloped empathic and affiliation tendencies observed in RDR patients may be predictive of the formation of maladaptive behavioral patterns.

3. Low communication resources in patients with RDR and in their reference relatives considerably complicate relationships in families of patients, reduce opportunities for social adaptation in members of communicative process and break the homeostasis of family system that must be considered when creating relevant psychoeducational and psychocorrection programs.

KEY WORDS: recurrent depressive disorder; empathy; affiliation; social intelligence.

Рукопис надійшов до редакції 11.05.2017

\author{
Відомості про авторів \\ Пшук Наталя Григорівна, д-р мед. наук, профресор, зав. кафр. медичної психології та психіатрії з курсом \\ післядипломної освіти Вінницького національного медичного університету ім. М.І. Пирогова
}

Камінська Анна Олексіївна, канд. мед. наук, доцент каф. медичної психології та психіатрії з курсом

післядипломної освіти Вінницького національного медичного університету ім. М.І. Пирогова, тел. 0979719887 